Multicultural Politics 



\section{Multicultural Politics}

Racism, Ethnicity and Muslims in Britain

Tariq Modood

Foreword by Craig Calhoun

Edinburgh University Press 
See pages 233-4 for copyright information for previously published material in this book.

(C) the Regents of the University of Minnesota, 2005

Transferred to Digital Print 2012

First published in the United States of America by

the University of Minnesota Press, 2005

Printed and bound by CPI Group (UK) Ltd, Croydon, CR0 4YY

A CIP record for this book is available from the British Library

ISBN 0748621717 (hardback)

ISBN 0748621725 (paperback)

The right of Tariq Modood to be identified as author of this work has been asserted in accordance with the Copyright, Designs and Patents Act 1988. 
To the memory of my father 
